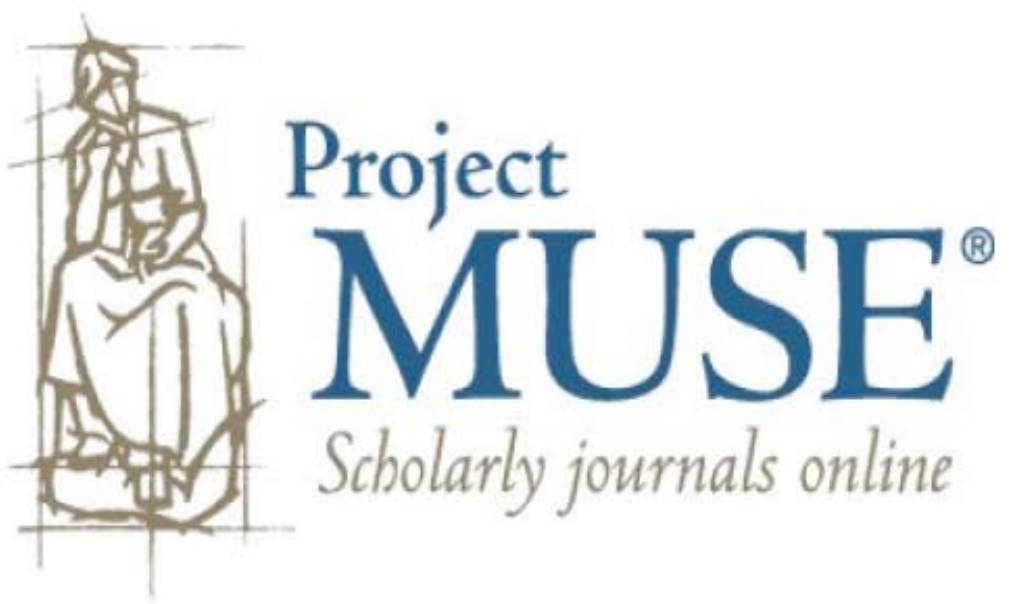




\title{
How Do Unions Renew? Paths to Union Renewal
}

\author{
Christian Lévesque and Gregor Murray
}

\begin{abstract}
How are unions responding to change? Are they renewing? Drawing on the CRIMT International Colloquium on Union Renewal, this introductory paper presents the overarching themes in this special thematic issue of Labor Studies Journal. After a synoptic overview of the range of cases and methodological issues highlighted by the papers, three sets of issues are presented: the need to enhance basic union efficiency or instrumentality, the importance of union governance and internal organization, and the need to rethink union resources. The development of collective identities, the mobilization of external expertise and networks, and the development of union leadership are identified as key resources in the union renewal process and as important subjects for further research.
\end{abstract}

T nions have had to contend with much change over the last two decades. Transnational economic restructuring and the relentless pursuit of labor flexibility decenter traditional modes of union action and weaken unions' abilities to defend their members. Long-term movements in the types of jobs people do and in the industries in which they do them, as well as the socio-demographic characteristics of these workers, raise the question of the ability of unions to move into new job territories and to reflect the diversity of people at work. The differing values people bring to work also challenge union identities and prevailing modes of collective action. And public policies have frequently sought to individualize the employment relationship to the detriment of union forms of collective representation. The capacity of unions to respond to these changes has sparked considerable debate and research. Whether it is labeled union renewal, revitalization, or some other term, a substantial body of academic research now deals with this phenomenon, especially but not exclusively in the Anglo-Saxon countries where the decline

Labor Studies Journal, Vol. 31, No. 3 (Fall 2006): 1-13. Published for the United Association for Labor Education by the West Virginia University Press, P.O. Box 6295, West Virginia University, Morgantown, WV 26506. (C) 2006, West Virginia University Press. 
of union density has been most evident. ${ }^{1}$

After two decades of research on union renewal, we might think that there is not much left to be said. Yet, quite different narratives still emerge about the diagnostics of change and the paths to union revitalization. Some analysts suggest that we now know what must be done, and the challenge is simply understanding why we are not doing it. Others see epochal social change that calls for the emergence of new forms of collective representation better suited to the changing situation of workers and their workplaces.

Many tensions run through the different understandings of what should be done. Readily familiar to observers of the U.S. labor movement, of course, is the tension between the "big bang" theories of necessary structural change, notably through mergers, and a strategy of internal experimentation seen as an incremental and organic approach to renewing union structures and practices. Similar tension is seen between top-down and bottom-up approaches, just as tension is evident between a focus on strategy and leadership, as opposed to democracy. Tensions also exist between fostering internal resources and developing networks and coalitions through external alliances. Contending visions of unionism are also at play, as in the emphasis on the transformation of labor markets and social systems through social movement unionism as opposed to institutional buy-in through workplace partnerships focused on ensuring a greater voice for unions and their members in the negotiation of workplace change. Of course, it is not "either/or" in most cases. Yet these tensions are real and part of an ongoing debate about the paths to union renewal. They are also integral to the challenge of developing renewal projects that ensure member adhesion.

With a view to understanding these tensions and to building bridges between current academic research on labor and employment issues and the experiences of union activists and staff, the Inter-University Research Centre on Globalization and Work (or CRIMT, which is the French language acronym for the Centre de recherche interuniversitaire sur la mondialisation et le travail) convened an International Colloquium on Union Renewal in Montreal in November 2004. ${ }^{2}$ The organizers felt the need to reinforce the links between different research communities, across national boundaries, and between the practitioners and the research community's analysts of union renewal. They also wanted to foster the building of further research capacity and further scientific accumulation through exchange about core insights into union renewal processes. Many organizations endorsed these objectives, which was evident in the support from both union and research organization partners.

In response to specific invitations and an international call for papers, 250 people from fifteen different countries participated, including academics, 
trade unionists, and other community partners. Many of the ninety-plus contributions are available on the CRIMT website (http://www.crimt.org/) and a dedicated interactive site on union renewal (http://www.crimt.org/Unionrenewal.html) (websites accessed July 17, 2006). Articles from the colloquium are also appearing in five labor and industrial relations journals across the world as well as a collection of studies on union renewal in Canada (Kumar and Schenk 2006). ${ }^{3}$ Of course, the objectives of the CRIMT Colloquium and those of the LSJ are so compatible that it was a natural fit, after external review, to publish some of the most interesting research results in this special issue of Labor Studies Journal. The editors of this special issue wish to give particular thanks to the editor, Bruce Nissen, and the former editor, Paul Jarley, for their support and intellectual input during the preparation of this issue.

This special issue features four empirical studies and this thematic overview. We first present the main themes emerging from these papers and then set out what we believe are some of the key lessons for thinking about the paths to union renewal.

\section{Thematic Overview of the Papers}

The four papers selected in this special issue offer an interesting range of themes for the analysis of potential paths for union renewal. Moreover, they draw on a wide range of union experiences: eleven cases in all, in three liberal market economies-Canada, Great-Britain, and the United States -where union action has been increasingly decentralized and subject to hostile public policies.

In the first paper, Jeremy Waddington is concerned with the perspectives of former union members, that is those who were once union members but are no longer so. He wants to know why members leave unions. In his view, while there is much concern with organizing and recruitment in the union renewal literature, scant attention is paid to the issue of retention. Yet, many lessons can be learned through this lens. He looks at union leavers in three British unions offering a range of labor market configurations: a union of white-collar workers organizing exclusively in the private services; a fairly heterogeneous union, made up of both blue-and white-collar workers, organizing in goods and the public and private services, and a primarily public services union organizing both blue- and white-collar workers.

In the second paper, Jack Fiorito and Vickie Coleman Gallagher recount the case of a local union of university professors in Florida that had to deal with the restructuring and radical decentralization of their bargaining unit, moving from statewide to local bargaining, and with the possibility of the employer choosing whether to bargain with employee unions or not. 
This onslaught, which challenged the very survival of their union, triggered several union responses ranging from legal to organizing actions. The story is particularly interesting because university professors are generally not known for their militancy. Their case offers the chance to test several ideas about the use of "organizing models" in the context of dire circumstances.

In the third paper, Jean-Noël Grenier is interested in how local unions in multinational firms contend with and influence changes in work organization. When multinational company headquarters bent on using transnational benchmarking programs to increase productivity introduce flexible working practices, are local unions inevitably weakened? Do such programs work in the same way and with the same effect in different sites of the same firm? He therefore focuses on two local unions in different Canadian provinces engaged in the manufacturing of power generators for the same division of the same multinational firm.

Finally, in the fourth paper, Larry Haiven focuses on the prospects for unionism in the so-called new economy. He is interested in workers in the realm of "deployers" of labor contracts as opposed to "employers" of labor. Through this distinction, he seeks to capture groups of workers in many Canadian industries who are now organized primarily as independent contractors. Do such "deployed" workers need collective representation? What forms might such organization take? In particular, Haiven focuses on workers whose sets of skills are defined by a relatively high degree of autonomy. In his view, these different groups of workers-who include musical performers, film and video artisans, fish harvesters, registered medical technologists and nurses, and computer specialists-highlight the need for collective representation and for thinking clearly about emergent forms of collective organization for such workers.

\section{Research Methodologies for Union Renewal}

The papers are meant to offer a forum for ideas about union renewal. First, the studies offer fascinating insights into the spectrum of union experience. Second, and especially important for researchers when facing the choices and challenges of doing research on unions, they underscore how studies of union renewal must be grounded in union practices and, hence, the importance of research partnerships. Third, and this is important for union activists and leaders when thinking about avenues of renewal, the papers point to how research can inform the renewal of union practice and, indeed, sometimes be used as a lever for renewal. Finally, the papers invite us all to think about how research can be improved and made more relevant to the renewal of union practice. 
Probably few researchers in the world have administered more questionnaires in collaboration with unions in different countries than Waddington who, over the last couple of decades, has conducted dozens of studies of union officials, delegates, staffs, and members. One methodological challenge he has sought to overcome is how to get an inside view of the union experience in a context where rapid job turnover and individual choice mean that many potential union members are now outside the union. Do former union members leave by choice or by circumstance? Are they likely to become members again? What was the quality of their union experience?

That is why Waddington focuses on the views of individual union leavers, namely those who were once union members but who are no longer so -despite the fact that many continue to work in the same workplace where their former union continues to operate. He then links the views of these individuals to the practices of the unions they left. This is especially important in countries where some combination of competition between unions and the individual choice to be a union member means that explanations as to why members leave unions and how union leavers perceive their union experience provide keys for understanding what's working and what's not working in the union experience. The methodological challenges of creating a substantial data bank of union leavers are daunting, to say the least, and Waddington reports on the views of 5,645 union leavers in three different unions. Most union researchers and union activists will readily appreciate the unique perspectives that such a study generates.

Fiorito and Coleman Gallagher provide a thick description of a single case to explore the internal dynamics of and challenges for a union in renewal. The methodological dimensions of this study are, however, more complex and multilayered. Fiorito is above all known to readers of the Labor Studies Journal and to the larger research community for his rigorous qualititative studies. In this case study, however, he seeks to apply a model, developed through quantitative analysis (Heery 2003; Fiorito 2004), to a single case. This case study is conducted through participant observation. One author is not only an academic observer but also the faculty union chapter president and a statewide faculty union vice-president during the period studied. The results that flow from this methodological mix demonstrate both how multiple methods enrich the research process and how we can think more broadly about this process.

One compelling aspect is how this kind of qualitative analysis allows the authors to explore the limits and further develop the different dimensions of key modeled variables derived from both qualitative and quantitative studies. A good example is that of the complex dynamic between leadership 
and democracy. This is a central dynamic in the union renewal process for which quantitative studies-critically helpful here in helping to identify a a core dynamic-can only scratch the surface in terms of the tensions and tradeoffs involved in being a leader and fostering democracy. This is not to suggest any facile conclusion that qualitative studies are somehow superior to quantitative studies but rather to see the important complementarities between the two methods.

The other compelling methodological aspect of the Fiorito and Coleman Gallagher study is the blend between the subjective and objective dimensions of their analysis. Currently, much social science debate has sought to reaffirm the singular importance of subjectivity in situated analysis. In other words, unlike the natural sciences, social situations studied in the social sciences are unique, and meaning can only be adequately gleaned through interaction with actors and their contexts (Flyvbjerg 2001). Participant observation provides one means to such understanding, and the quality of this understanding is all the more interesting in this study because of the authors' tradition of "hard" quantitative analysis.

Grenier's study highlights the methodological gains of "deep" case studies. Over the course of both his M.A. and Ph.D. research, a period covering several years, he conducted 164 interviews in the two plants studied as well as engaging in participation observation, during which time he spent forty-two days on the shop floor. His data on each local union comes from leaders, staff, activists, and members as well as managers at various levels. This plurality of perspectives, with multiple takes over time on the same reality, helps to construct and validate meaning. Grenier's matched pair of cases offers greater analytical traction as to the importance of certain internal and external union resources relative to the context in which they are to be mobilized. This allows him to study how the local unions respond to the same benchmarking programs, albeit in different product market situations. It is the technique of the matched pair that allows Grenier to better understand the interplay between union resources and their context.

Finally, Haiven's research is informed by a context of de-industrialization. Over recent years, he has been concerned about how working communities develop their economy in response to the closure of traditional industries. He has focused particularly on Cape Breton Island-a region of the Canadian province of Nova Scotia-which has been affected by the closures of the mining and steel industries that once drove the regional economy. In their place, and in a context of endemically high unemployment, have emerged various economic activities ranging from cultural to high tech industries such as call centers. The old industries were, of course, characterized by relatively stable employment 
relationships in fixed locations over long periods of time. Workers in the new economy industries face much more precarious employment circumstances, combining high skill with a flow of interrelated work activities-sometimes paid by others through contracts and fees and sometimes the result of their own capital and time. Yet their situation at work calls for collective action and collective services in a variety of ways. Haiven is thus able to explore the dynamics of collective action and individual activity. Some might see these experiences as alternatives to union representation. Others would see these experiences as prefigurative forms of new kinds of hybrid unionism -drawing on practices associated with collective bargaining, professional associations, life styles, and community economies. The selection of such a wide range of cases-ostensibly without the initial common theme of sector or industry-helps us to think outside the box and to explore what might be different types of platforms for collective representation.

\section{Key Issues for Union Renewal}

So what are the major lessons that can be drawn from these four papers, and how do we take them further in terms of thinking about union renewal? Simply put, we see three sets of issues for both union activists and researchers: the need to enhance basic union efficiency or instrumentality, the attention to union governance and internal organization and, most critically, the importance of and need to rethink the range of union resources.

First, and this translates the amplitude of the question of union renewal, the current context questions the basic efficiency and even the instrumentality of unions. The ability to negotiate collective agreements that ensure decent working conditions is under challenge.

Irrespective of the three national contexts dealt with in these papers, clearly the contours of the employment relationship are changing. Be it in terms of the privatizations affecting the union members studied by Waddington, or the successive flexiblizations impacting the manufacturing workers in Grenier's paper, or the state's decentralization of the bargaining process and ultimately the de-unionization of faculty professors in Fiorito and Coleman Gallagher's study, or the transformation of the very nature of the employment relationship described by Haiven in the movement from employers to deployers, each transformation exerted tremendous pressures on the capacity of unions to regulate the employment relationship. Such pressures speak to the core of union capacity and instrumentality: namely, can unions still do what they are supposed to do?

This is clear in the case of Waddington's paper where the perception of an inability to deliver basic services (solving members' problems and im- 
proving working conditions) becomes one of the main drivers for members' decisions to leave their unions. Similarly, Grenier's study of the Guelph ABB plant highlights the sheer adversity of the context and how this challenges the union's capacity to deliver the traditional package of union goods. The investigation of university professors by Fiorito and Coleman Gallagher shows how the kinds of pressures highlighted by Grenier are by no means unique to the private sector. The decision to decentralize the level of bargaining and give the employer the choice of whether to deal with the union or not was clearly hostile to the union studied and could have reduced its capacity to represent its members and, by the same token, to protect and improve their working conditions. Finally, Haiven's study of union and nonunion zones highlights how employer/deployer resistance to unionization is often quite effective in thwarting ambitions to collectivize. At the same time, he emphasizes how many of the emblematic professions of the new economy need the benefits of collectivization. Yet basic instrumentality is difficult to bring to these workers, even though it might well be beneficial for both workers and their deployers.

These experiences do not suggest that unions do not every day improve their members' lives. That union members are reluctant to give up collective protections and, by and large, wish to remain union members is eloquent testimony to the continued existence of union instrumentality. Yet important issues are raised by declining instrumentality, as illustrated by these papers and a larger context of continuing union concessions on wages and benefits and of the difficult transition of so many younger workers into the labor market. The traditional union model suggested that a minimal pool of resources and some capacity to coordinate negotiations should lead to acceptable outcomes. However, the pressures are now such that unions need to look to new sets of resources and new levers of power (Lévesque and Murray 2002), probably in more varied circumstances, in order to enhance the gains associated with union membership by union members.

The decline in instrumentality leads us to a second set of issues for thinking about union renewal. A clear recurring theme in the plurality of situations observed in these papers is the need to renew with core union functions and to attain greater levels of efficiency in the ways that unions achieve their core objectives. This nuts and bolts understanding leads us to look at union governance and internal organization. In other words, how unions are organized, in terms of communication, participation, or coordinated action, seems to matter to both levels of efficiency and a sense of belonging. For Waddington, the key to membership retention strategies is the ability to enhance membership identification through new forms of governance that increase 
representation and participation. Similarly, union efficiency-its ability to deliver the goods-creates a virtuous circle in terms of enhanced militancy and activism on the part of union membership. That is certainly a major conclusion of Fiorito and Coleman Gallagher's study. Likewise, in Grenier's paper, the contrasting fortunes of the unions in the two plants studied are directly linked to the relative performance of the local unions. Where the local union is unable to fulfill core functions, there is basic disaffection, but when the union is able to influence working conditions, its capacity is enhanced for generating membership in and identification with the local union. Haiven's study presents a mixed case. While a central function of all unions is to connect with the basic needs of their members generated by the cross-cutting forces of mutuality or the need to cooperate, and this is a fundamental continuity, the shift of the contours of the employment relationship limits the capacity of unions to play this role and points to the need to look at entirely new and often discontinuous forms of collective representation. His key conclusion suggests the need to think differently outside the traditional "union zone" and to look to new organizational forms likely to generate collective identities and to respond to worker needs.

The third set of issues concerns the importance of and need to rethink the range of key union resources. From the papers in this special issue emerge important resources that merit particular consideration: collective identities, external expertise and networks, and union leadership.

At the core of the current challenge to unions is the question of generating and maintaining strong collective identities. Workers' collective identities and union members' identification with their union are key resources that are being buffeted by shifting values and ideologies and by the destructuring and restructuring of jobs, industries, and communities. Collective identities are not a given; they are constructed and reconstructed through narrative framing and the engagement of individuals in debates about what to do and why. Such processes highlight the importance of internal union mechanisms that reflect collective identities and provide a space for generating new identities and activism.

Waddington provides a major insight for current thinking about union structures. According to his study of union leavers, the conglomeration of unions through mergers risks alienating members who no longer find adequate space for their particular needs and identities within these larger structures. The inability to provide sufficient membership proximity to larger union structures points to huge risks associated with multiple mergers that might well offer administrative efficiencies and financial leverage but do not take account of the need to foster collective identities. Haiven points to a similar 
conclusion. Workers in the new economy need unions, but they are unlikely to opt for forms of unionism that do not heed issues centered on professional identities. For Grenier, the central dynamic in constructing union responses to transnational pressures on the workplace can be defined in terms of the ability of local unions to provide a continuous two-way flow of information between members and local leaders. Finally, in the view of Fiorito and Coleman Gallagher, external constraint becomes an opportunity for union renewal inasmuch as the union can move "closer to the members." It is quite clear from the four papers that practice of democracy and the structures that underpin it are a resource that matters, notably in terms of their contribution to union collective identities and the activism that flows from them.

The changing context of workplaces means that a local union can no longer rely only on local resources to defend its members. This points to a second key area for rethinking the range of union resources: how to tap into external expertise and networks. The expertise available from external affiliations and the coordination that flows from involvement in larger union forums and external networks mean that the development of external resources is an essential tool for union renewal. For Grenier, the absence of external resources, especially in a context of increased transnational pressures on employment, limited the capacity of one of the local unions under investigation to educate its members about broader trends and to influence change in that workplace. Similarly, Fiorito and Coleman Gallagher highlight how the success of their local union's campaign was connected to a broader statewide coalition. It was the combination of these interdependent local and statewide actions that permitted these faculty unions to better defend the working conditions of their members. Finally, Haiven points to the importance of legislative frameworks for the emergence of new representative forms and the need to find synergies between professional associations and unions to attend to the needs of new economy workers.

Union leadership is the third resource that emerges from the contributions to this special issue. Leadership, of course, refers to the ability to pursue renewal projects but also to the ability to read and anticipate changes in a union's environment and to develop compelling responses to those changes. It is also the capacity to read change within union organizations, to mediate a diversity of interests at play, and to translate them into a common narrative about where the union is and should be going and why.

The importance of leadership, as a strategic resource for union renewal, certainly emerges from the four papers. Grenier highlights the critical importance of the ability of the local union to propose plausible and even convincing alternatives to management projects involving the reorganization 
of work. Fiorito and Coleman Gallagher stress the importance of different levels of leadership within the union (statewide and locally) in the ability to interpret threats and develop plans in response to those threats and, most critically, in building membership identity and activism on the basis of those projects. For Waddington, union leaders must focus on what makes members want to remain union members in order to understand what might convince nonmembers to join. In Haiven's study, leadership involves thinking outside the box, looking at new interpretations of worker needs and new mechanisms and services that give voice to these needs beyond the "Wagnerist" model.

Of the three resources highlighted here, leadership is undoubtedly the most intractable. It is embedded in particular contexts in which individuals and groups have to make particular choices. Some of these choices can be explained by past trajectories and generational cohorts. Some can be explained by their interrelations with other resources at play and the way that these other resources structure the range of possible choices. Some are shaped by individual life experiences that might have little relation to the immediate context.

There is clearly a huge need for research on the development and mobilization of union resources. How are union resources mobilized in particular contexts? How do these contexts situate resources and their relevance? How is union leadership shaped by its interactions with union democracy and external resources? How can leadership enhance these resources? How can union leadership and strategic capacity be renewed in particular contexts in order to respond to the central problems of union efficiency and instrumentality? While the four papers that follow do not provide definitive answers to all of these questions, they provide useful insights to stimulate our thinking about how unions renew. Much research remains to be done on this theme, and these papers provide valuable contributions to this agenda.

\section{Notes}

1 See, for example, Bronfebrenner et al. (1998), Clawson (2003), Fairbrother and Griffin (2002), Fairbrother and Yates (2003), Fantasia and Voss (2004), Frege and Kelly (2004), Milkman and Voss (2004), Nissen (1999), Peetz (1998), Turner, Katz and Hurd (2001), Turner (2005), and almost any issue of Labor Studies Journal over the last five years.

2 This initiative, entitled "Rethinking Institutions for Work and Employment in a Global Era," was part of a major collaborative research initiative project, initiated by CRIMT and funded by the Social Sciences and Humanities Research Council of Canada. 
3 In addition to this special issue of Labor Studies Journal, see issues of Just Labour (2005), Transfer (2005), and forthcoming issues of Relations industrielles/Industrial Relations (2006) and La Revue de l'IRES (2007).

\section{References}

Bronfenbrenner, Kate, Sheldon Friedman, Richard W. Hurd, Ron A. Oswald, and Richard L. Seeber, eds. 1998. Organizing to win: New research on union strategies. Ithaca: ILR Press.

Clawson, Dan. 2003. The next upsurge and the new social movements. Ithaca and London: ILR/Cornell University Press.

Fairbrother, Peter, and Gerard Griffin, eds. 2002. Changing prospects for trade unionism. London: Continuum.

Fairbrother, Peter and Charlotte Yates, eds. 2003. Trade unions in renewal: A comparative study. London/New York: Continuum

Fantasia, Rick, and Kim Voss. 2004. Hard work: The remaking of the American labor movement. Berkeley, C.A.: University of California Press.

Fiorito, Jack. 2004. Union renewal and the organizing model in the United Kingdom. Labor Studies Journal 29, no. 2:21-53.

Flyvbjerg, Bent. 2001. Making social science matter. Cambridge: Cambridge University Press.

Frege, Carola, and John J. Kelly, eds. 2004. Varieties of unionism: Strategies for union revitalization in a globalizing economy. Oxford: Oxford University Press.

Heery, Edmund. 2003. Trade unions and industrial relations. In Understanding work and employment, edited by Peter Acker and Adrian Wilkinson. Oxford: Oxford University Press.

Kumar, Pradeep, and Christopher Schenk, eds. 2006. Paths to union renewal: Canadian experience. Calgary: Broadview Press.

Lévesque, Christian, and Gregor Murray. 2002. Local versus global: Activating local union power in the global economy. Labor Studies Journal 27, no. 3:3965.

Milkman, Ruth, and Kim Voss, eds. 2004. Rebuilding labor: Organizers and organizing in the new union movement. Ithaca and London: ILR/Cornell University Press.

Nissen, Bruce, ed. 1999. Which direction for organized labor? Essays on organizing, outreach and internal transformations. Detroit: Wayne State University Press.

Peetz, David. 1998. Unions in a contrary world: The future of the Australian trade union movement. Cambridge: Cambridge University Press. 
Turner, Lowell. 2005. From transformation to revitalization: A new research agenda for a contested global economy. Work and Occupations 32, no. 4:383. 399.

Turner, Lowell, Harry Katz, and Richard Hurd. 2001. Rekindling the movement. Ithaca: Cornell University Press. 